\title{
Uncommon presentation of CAPD-related peritonitis with unusual organism: Kocuria kristinae. Case report and review of the literature
}

\author{
Sürekli periton diyalizi ilişkili peritonit: Kocuria kristinae. Olgu sunumu ve literatür derlemesi \\ Dilek BARUTCU ATAS, Hakki ARIKAN, Basar AYKENT, Ebru ASICIOGLU, Arzu VELIOGLU, Serhan TUGLULAR, \\ Cetin OZENER
}

\begin{abstract}
Kocuria kristinae is a gram-positive coccus of Micrococcaceae family. Kocuria kristinae inhabits the skin and mucous membranes. It can cause opportunistic infections in patients with indwelling devices and severe underlying diseases.

We describe here a case of acute peritonitis caused by Kocuria kristinae in a patient on continuous ambulatory peritoneal dialysis (CAPD). Additionally, a review of other reported CAPD related peritonitis by Kocuria kristinae is provided.

The importance of Kocuria kristinae as a pathogen in patients with CAPD peritonitis should not be underestimated.
\end{abstract}

Keywords: Back pain, Kocuria kristinae, Peritonitis, Peritoneal dialysis

ÖZ

Kocuria kristinae, Micrococcaceae ailesinden gram pozitif kok şeklinde bir bakteridir Kocuria kristinae deride, mukoza ve orofarinkste kolonize olur. İmmünosüprese hastalarda oportünist bir patojen olarak infeksiyonlara neden olabilir.

$\mathrm{Bu}$ yazıda sürekli ayaktan periton diyalizi (SAPD) tedavisi gören bir hastada Kocuria kristinae ye bağlı gelişen akut peritonit olgusu sunulmuştur. Diğer SAPD tedavisi gören hastalardaki Kocuria kristinae peritonitleri gözden geçirilmiştir.

SAPD tedavisi gören hastalarda Kocuria kristinae patojen olarak bildirildiğinde bu mikroorganizmanın klinik önemi küçümsenmemelidir.

Anahtar kelimeler: Bel ağrısı, Kocuria kristinae, Peritonit, Periton diyalizi

Dilek Barutcu Atas (两), Hakki Arikan, Basar Aykent, Ebru Asicioglu, Arzu Velioglu, Serhan Tuglular, Cetin Ozener

Division of Nephrology, Department of Internal Medicine, School of Medicine, Marmara University, Pendik, Istanbul, Turkey

e-mail:drdilekb@gmail.com,dbarutcu@marmara.edu.tr

Submitted / Gönderilme: 18.10.2016

Accepted/Kabul: 03.12.2016

\section{Introduction}

Kocuria kristinae is a gram positive coccus of a member of Micrococcaceae family. Kocuria species are ubiquitous in the environment and part of normal skin and oral flora of humans and other mammals [1]. Kocuria species can rarely be opportunistic pathogens; in particular, Kocuria kristinae is the species most frequently isolated from immunocompromised patients [2].

Currently, there are only two reported cases of Kocuria kristinae-related peritonitis in patients with peritoneal dialysis (PD) in the literature. Here, we report a case of Kocuria kristinae peritonitis in a patient undergoing CAPD.

\section{Case Report}

A 56-year-old woman with end-stage renal disease due to hypertensive nephropathy who had been on CAPD four exchanges a day, for three years was admitted to our outpatient clinic for the first time because of fatigue, loss of appetite and back pain. The severe back pain had been present for four months. Three weeks ago, lumber magnetic resonance (MR) imaging revealed only minimal disc herniation. On physical examination blood pressure was $131 / 78 \mathrm{~mm} / \mathrm{Hg}$, body temperature was $36.7^{\circ} \mathrm{C}$. Interestingly, there was no abdominal pain or tenderness. Laboratory data showed leukocytes count as $8,100 / \mu \mathrm{L}$ (normal) with $80.1 \%$ of polymorphonuclear cells, high $\mathrm{C}$ reactive protein (CRP) level $[103 \mathrm{mg} / \mathrm{L}(\mathrm{N}: 0-5)]$ and high sedimentation rate [111 $\mathrm{mm} / \mathrm{h}(\mathrm{N}: 0-30)]$. We noticed that the dialysis effluent was turbid. The white cell count of dialysate was above 10,000/ $\mu \mathrm{L}$. Blood and peritoneal fluid cultures were taken. Direct gram stain showed gram-positive cocci in peritoneal fluid. Empirical antibiotic treatment with intraperitoneal sefuroxim 
axetil (750 mg twice a day) and oral ciprofloxacin (500 mg twice a day) was started. The peritoneal fluid culture revealed Kocuria kristinae which was sensitive to sefuroxim axetil and ciprofloxacin. By day seven of empirical treatment, the peritoneal fluid became clear, with dialysate white cell count completely normalized. After three weeks of intraperitoneal sefuroxim axetil and ciprofloxacin, the patient's complaints including back pain, fatigue and loss of appetite resolved completely. Control peritoneal fluid culture were negative and laboratory data showed normal CRP level [4 mg/L (N: $0-5)]$ and sedimentation rate $[59 \mathrm{~mm} / \mathrm{h}(\mathrm{N}: 0-30)]$. There was no relapse of peritonitis and back pain upon two months of follow-up.

\section{Discussion}

Kocuria kristinae inhabits skin and mucous membranes. Even though it is considered to be non-pathogen, it can cause opportunistic infections in patients with indwelling devices and severe underlying diseases. Infections due to Kocuria kristinae are uncommon but are increasingly being recognized [3-6]. In recent years, Kocuria kristinae was reported as a primary pathogen in cases of catheter related bacteraemia and infective endocarditis [3], bacteremia with acute leukemia [4], pregnant female [5] and acute cholecystitis [6].
Kocuria kristinae was reported to be susceptible to many commonly used antibiotics including doxycycline, ceftriaxone, cefuroxime, amikacin, ciprofloxacin and amoxicillin with clavulanic acid. The emergence to ampicillin and erythromycin resistance has been reported in a small number of patients [7].

After careful review of the literature, we found only two cases of Kocuria kristinae infections in patients with CAPD-related peritonitis. The first case was a 78-year-old man from Italy who was admitted to hospital with abdominal pain, fever and cloudy peritoneal dialysate. He has been managed with combination therapy with ciprofloxacin, teicoplanin and amoxicillin/clavulanic acid for a total of three weeks duration [8]. The second case was a 69-year-old man from China who was presented with abdominal pain, turbid peritoneal dialysate fluid for three days. He has been managed successfully with cefazolin for two weeks [9]. Our patient was admitted to hospital with fatigue, loss of appetite and back pain and after three weeks of intraperitoneal sefuroxim axetil and ciprofloxacin her symptoms resolved completely (Table 1). In addition, our patient did not have any abdominal pain or tenderness expected in an acute peritonitis attack when she was admitted to outpatient clinic. No case of peritonitis presenting with long standing

Table I: CAPD-related peritonitis with Kocuria kristinae

\begin{tabular}{|l|l|l|l|l|l|l|}
\hline Age & Sex & $\begin{array}{l}\text { Type of } \\
\text { dialysis }\end{array}$ & Presentation & Treatment & Response to therapy & References \\
\hline 78 & Male & CAPD & $\begin{array}{l}\text { Abdominal pain, } \\
\text { fever, cloudy } \\
\text { peritoneal } \\
\text { dialysate. }\end{array}$ & $\begin{array}{l}\text { Empirically: Cefotaxime plus tobramycin IP, } \\
\text { tazobactam IV for 6 days. } \\
\text { According to antibiotic susceptibility adjusted } \\
\text { to ciprofloxacin plus teicoplanin IP and } \\
\text { amoxicillin/ clavulanic acid IV for 10 days } \\
\text { After 10 days of specific treatment discharged } \\
\text { from hospital and 14 days ciprofloxacin orally }\end{array}$ & $\begin{array}{l}\text { Without catheter } \\
\text { removal or } \\
\text { recurrence }\end{array}$ & $\begin{array}{l}\text { Carlini et al.[8] 2011, } \\
\text { Italy }\end{array}$ \\
\hline 69 & Male & CAPD & $\begin{array}{l}\text { Abdominal pain, } \\
\text { turbid peritoneal } \\
\text { dialysate fluid for } \\
\text { 3 days }\end{array}$ & $\begin{array}{l}\text { Empirically: cefazoline and cefepime IP for 4 } \\
\text { days } \\
\text { According to antibiotic susceptibility adjusted } \\
\text { to cefazoline } \\
\text { A total of two weeks cefazolin }\end{array}$ & $\begin{array}{l}\text { Without catheter } \\
\text { removal or } \\
\text { recurrence }\end{array}$ & $\begin{array}{l}\text { Cheung et al. [9] } \\
\text { 2011, China }\end{array}$ \\
\hline 56 & Female & CAPD & $\begin{array}{l}\text { Back pain, } \\
\text { fatigue, loss-of } \\
\text { appetite, turbid } \\
\text { peritoneal } \\
\text { dialysate }\end{array}$ & $\begin{array}{l}\text { Empirically: sefuroxim axetil IP and oral } \\
\text { ciprofloxacin } \\
\text { A total of three weeks sefuroxim axetil and } \\
\text { ciprofloxacin. }\end{array}$ & $\begin{array}{l}\text { Without catheter } \\
\text { removal or } \\
\text { recurrence }\end{array}$ & $\begin{array}{l}\text { Index case 2015, } \\
\text { Turkey }\end{array}$ \\
\hline
\end{tabular}

CAPD: Continuous ambulatory peritoneal dialysis; IP: intra-peritoneal 
back pain has ever been reported. In this regard, our case is interesting because of uncommon presentation with unusual microorganism.

In conclusion, Kocuria kristinae had been rarely identified as a causative agent in CAPD-related peritonitis. However, we should not clinically underestimate the importance of Kocuria kristinae as a pathogen in patients with CAPD peritonitis when Kocuria kristinae is yielded from peritoneal effluent specimens. We need more reports about Kocuria kristinae infections in order to understand its clinical spectrum.

\section{Disclosure}

The authors declare there are no conflicts of interest

\section{References}

1. Szczerba I. Occurrence and number of bacteria from the Micrococcus, Kocuria, Nesterenkonia, Kytococcus and Dermacoccus genera on skin and mucous membranes in humans. Med Dosw Mikrobiol 2003; 55:67-74.

2. Stackebrandt E, Koch C, Gvozdiak O, Schumann P. Taxonomic dissection of the genus Micrococcus: Kocuria gen. nov., Nesterenkonia gen. nov., Kytococcus gen. nov., Dermacoccus gen. nov., and Micrococcus Cohn 1872 gen. emend. Int J Syst Bacteriol 1995;45:682-92. doi: 10.1099/00207713-45-4-682

3. Lai CC, Wang JY, Lin SH, et al. Catheter-related bacteraemia and infective endocarditis caused by Kocuria species. Clin Microbiol Infect 2011;17:190-2. doi::10.1111/j.14690691.2010.03211.x

4. Martinaud C, Gaillard T, Brisou P, Gisserot O, de Jaureguiberry JP. Bacteremia caused by Kocuria kristinae in a patient with acute leukaemia. Med Mal Infect 2008; 38:334-5. doi: 10.1016/j.medmal.2008.02.006

5. Dunn R, Bares S, David MZ. Central venous catheterrelated bacteremia caused by Kocuria kristinae: case report and review of the literature. Ann Clin Microbiol Antimicrob 2011; 10:31. doi: 10.1186/1476-0711-10-31.

6. Ma ES, Wong CL, Lai KT, Chan EC, Yam WC, Chan AC. Kocuria kristinae infection associated with acute cholecystitis. BMC Infect Dis 2005; 5:60. doi:10.1186/14712334-5-60

7. Szczerba I. [Susceptibility to antibiotics of bacteria from genera Micrococcus, Kocuria, Nesterenkonia, Kytococcus and Dermacoccus]. Med Dosw Mikrobiol 2003; 55:75-80.

8. Carlini A, Mattei R, Lucarotti I, Bartelloni A, Rosati A. Kocuria kristinae: an unusual cause of acute peritoneal dialysis-related infection. Perit Dial Int 2011; 31:105-7. doi: 10.3747/pdi.2010.00132.

9. Cheung CY, Cheng NH, Chau KF, Li CS. An unusual organism for CAPD-related peritonitis: Kocuria kristinae. Perit Dial Int 2011; 31:107-8. doi: 10.3747/pdi.2010.00125 